Covered in: ERIH PLUS, HeinOnline, CEEOL, Index Copernicus, CrossRef, CrossCheck, J-GATE, Google Scholar, Ideas RePeC, Econpapers, Socionet, KVK, WorldCat.

2019, Volume 7, Issue 2, pages: 10-29 | doi: 10.18662/lumenlaw/24

\section{Migration - an \\ Overview on Terminology, Causes and Effects}

\section{Georgiana Florentina TATARU1}

${ }^{1}$ LLM (Business Law) student at Alexandru Ioan Cuza University of Iași, Faculty of Law, Romania, email: florinatataru@gmail.com

\begin{abstract}
Given the fact that migration is a frequent debated worldwide issue, it is of great importance to have a welldefined and clear representation of what this phenomenon means for the individuals, for state-nations and for society as a whole. In order to achieve that, the present paper aims to differentiate between the types of migration, its subjects (asylum seekers, refugees, migrant workers, etc.), as well as to emphasize what are the triggering factors and the effects of this mass movement that has been present in our global society since the very beginning.
\end{abstract}

Keywords: migration; refugee; asylum; expat; international public law; push-pull factors.

How to cite: Tataru, G.F. (2019). Migration - an Overview on Terminology, Causes and Effects. Logos Universality Mentality Education Novelty: Law, 7(2), 10-29. doi:10.18662/lumenlaw/24 


\section{Introduction}

Migration has been a constant and persistent feature in the history of humankind, being among the most important and pressing global issues of our time. When people cross the border of a country, a metamorphosis happens to their legal status. They suddenly gain a special label or status - of migrants.

Migration is a phenomenon of great complexity. The reasons people migrate are varied and constantly changing. Moreover, the individuals who migrate are not easy to classify due to the fact that they come under different circumstances, from different environments and with different individual characteristics. Accordingly, understanding the causes and consequences of migration, as well as acquiring theoretical and practical skills are essential for both tackling the challenges that arise and developing effective policies to protect migrants.

We live in a constantly changing world, where migrants have a significant impact on the economic, political and social agendas of sovereign states, intergovernmental agencies and civil society groups. In the times of contemporary globalization, the laws on migration and their application are increasingly understood as the last bastion of sovereignty, therefore having repercussions on their character, their content and the political vision of the state. Furthermore, of great importance is placing the fundamental human rights at the core of migration and asylum policies.

Our world is made of states and individuals - who constantly come and go. It is also a world of borders that people cross for many reasons: to work, to visit their families, to escape violence and natural disasters, to study, to heal or to return to their country. Migration is not the mere act of crossing the border, but an important factor in the erosion of traditional boundaries between languages, cultures, ethnic groups and nation-states, affecting all those involved.

Migration, as a whole, captures a dynamic, constantly changing reality. Since its inception, the migration phenomenon is manifesting on a global level, with advantages and disadvantages and represents an indisputable element of our age, which influences the social and economic life of the states. Faced with this reality, the governments of the world have to seek the most effective ways of interstate cooperation regarding migration.

In recent decades, the process of globalization has significantly increased international migration, especially to developed countries. The 
study of migrants, their economic motivation, as well as the consequences of this migration have become important topics for various researches, analyzes, as well as for the international political agenda.

The free movement of persons is part of a myriad of problems, combined with terrorism and territorial security, with the protection of fundamental human rights, as well as with the permanent need for improvement and adjustment of government in order to streamline population control in sovereign states. (Dragoman \& Ungureanu, 2018: 407)

The display of these complex realities in national, European and international legislation offers a special perspective on them, as the globalization of problems, their great extent, accelerated external rbythms of change, unpredictability and the extent of the effects of human actions imply a radical change in the legal framework in which these phenomena take place". (Dragoman \& Ungureanu, 2018: 407)

Adjacently, the demographic and social structure of industrialized states has created a need for workers and professionals from other countries, who are recruited to support economic expansion, to stimulate development and to stop short-term fluctuations in jobs. (Altermatt, 2000; Trocan, 2014: 155)

Both the aging of the population, as well as the increase in demand for personal and household services registered in rich countries, have led to an increase in the labor market offers for unskilled foreign workers. At the same time, skilled workers with higher education have increased international mobility.

\section{Conceptual and terminology delimitations}

In order to better understand migration, we need to start from its nucleus - the individual human being, as the triggering entity of the phenomenon. Starting from the famous quote of Socrates: "I am neither Athenian nor Greek, but a citizen of the world" (Plutarch, 1949) - but also from the abstract way that international conventions chose to refer to individuals, presenting them through the concept of "human beings" (for example, the Universal Declaration of Human Rights), we can believe the idea that, first of all, every person represents a physical entity with certain capacities or attributes, such as reason, morality, conscience and which, through their own identity and kinship, is part of a predefined social ensemble.

Closely related to the notion of person is the notion of citizenship (Balan, 2015: 309) which, as a legal institution, represents "the set of legal rules regulating the belonging of an individual to a particular state, the ways in which this 
membership arises, is maintained and ceased, as well as the rights and specific obligations to those bound by such relations of belonging."

Article 15 para. (1) of the Universal Declaration of Human Rights (United Nations, 1948) provides that nationality is a right of any person, and para. (2) provides that "No one shall be arbitrarily deprived of his nationality nor denied the right to change his nationality".

At the same time, the International Covenant on civil and political rights recognizes, through the provisions of article 16, the recognition of citizenship (Moldovan, 2015: 149), more precisely the right of any person to recognition everywhere as a person before the law (United Nations, 1976).

On the account of citizenship, the natural person enjoys all the rights and obligations deriving from this statute. However, it should be mentioned that some rights and obligations (such as exclusive political rights, the right to be diplomatically protected, fidelity to the homeland, etc.) can be exercised and assumed only by citizens. All these rights and obligations give the citizen a full legal capacity which foreign citizens or stateless persons do not benefit from.

Due to the recognized freedom of states to establish the rules for granting citizenship, the definition of the notion of foreigner may differ from state to state (Dupuy, 1998; Moldovan, 2015: 160). The notion of foreigner characterizes a natural person who is in the territory of a state, without having its citizenship. This concept encompasses several categories of persons: residents and non-residents, immigrants or non-immigrants, asylum seekers and refugees.

According to the $2^{\text {nd }}$ edition of The Explanatory Dictionary of the Romanian Language (DEX II, 1998: 632), "migration" is defined as "the mass movement of some tribes or populations from one territory to another, determined by economic, social, political or natural factors". The Longman Dictionary of Contemporary English defines "migration" as that phenomenon "when large numbers of people go to live in another area or country, especially in order to find work." (Longman, 2005: 1040).

Migration represents the crossing of an administrative unit`s border for a certain minimum period of time. This category includes: refugee migration, economic migration, as well as the migration of people who move for other purposes or under the influence of other factors, such as family reunification.

Numerous empirical studies (Williams, 2006; Sulima, 2015: 283) define migration as a phenomenon that includes the simultaneous change of three major parameters: 
a) a change of domicile that involves the crossing of a political or national border;

b) a change of the place where they carry out their professional activity (even if they practice the same profession);

c) a change of social relations (the entry into a new community).

Migration can be both internal and international. Internal migration refers to the passage from one area (province, county, municipality) to another area within the territory of the same state. International migration is a territorial relocation of people between states - nations.

From this comprehensive definition, two forms of relocation can be excluded: first, the territorial movement which does not lead to any change of the bonds of social belonging and, therefore, remains irrelevant for both the individual and the society (e.g. tourism); secondly, relocation is excluded where individuals or groups concerned are purely passive objects, not active agents of the movement (for example, the organized transfer of refugees from their home states to a safe haven) (United Nations Educational, Scientific and Cultural Organization, n.d.).

Migration is usually divided into two categories: voluntary migration and forced migration.

Voluntary migration is based on the initiative and the free will of the person and is influenced by a combination of factors: economic, political and social: either in the the migrants ' country of origin (determinant factors or "push factors") or in the country of destination (attraction factors or "pull factors").

"Push-pull factors" are the reasons that push or attract people to a particular place. "Push" factors are the negative aspects of the country of origin, often decisive in people`s choice to emigrate and the "pull" factors are the positive aspects of a different country that encourages people to emigrate in search of a better life. Although the push-pull factors are apparently diametrically opposed, both are sides of the same coin, being equally important.

Although specific to forced migration, any other harmful factor can be considered a "push factor" or determinant / trigger factor, such examples being: poor quality of life, lack of jobs, excessive pollution, hunger, drought or natural disasters. Such conditions represent decisive reasons for voluntary migration, the population preferring to migrate in order to prevent financially unfavorable situations or even emotional and physical suffering. One such example is the Great Irish Famine (1845-1849), which forced thousands of Irish families to emigrate to the United States to avoid starvation (Rosenberg, 2019). 
On the other hand, the "pull factors" or attraction factors are present in the receiving states. The promise of religious or political freedom, career opportunities, quality of life and the environment, are factors of attraction for immigrants.

We consider that, generally, the voluntary migrants are more likely to emigrate to more developed states due to the ethnic, religious and cultural tolerance, the perspective of the higher wages, the opportunities for better employment and, often, the desire to escape the internal social and political situation of their country of origin. These migrants are mostly coming from countries with low or medium incomes, where, paradoxically, the population, motivated by the perspective of emigration, has a greater interest for professional development.

There is also an opinion that states that the movement of people across international borders concerns, separately, three categories of persons: refugees, international travelers and migrant workers (labor migration). This perspective represents an important innovation in recognizing the different dimensions of international mobility (Koslowski, 2011; Money \& Taylor, 2016: 7).

With 257.7 million international migrants globally (according to statistics compiled by UNDESA in 2017) (United Nations Department of Economic and Social Affairs, 2017), of which almost 70 million people were forced (United Nations High Commissioner for Refugees, 2018) to relocate and the increasing use of the terms "migrant" and "refugee" in the media and public discourse, a clear delineation of these terms is required.

Thus, a migrant is that person who moves from one place to another, who crosses an international border or moves within a state, away from the place of residence or family, overlooking the legal status of a person, the type of travel (voluntary/ involuntary) or the factors that caused the displacement.

However, an universally accepted definition for the term "migrant" has yet to be outlined. The term was usually interpreted to cover all cases where the decision to migrate was made freely by the individual concerned and without the intervention of an external determining factor; consequently, this also applies to the people moving to another country or region to improve their living and working conditions for themselves and their family members.

The United Nations (UN) defines the migrant as a person who has resided in a foreign country for a period of more than one year, regardless of the causes underlying the change of address and the means used to migrate. 
Under such a definition, those traveling for shorter periods, as tourists or business people, are not considered migrants (IOM, 2011).

Migrant workers, whom some authors call de facto refugees or economic refugees, given that they do not leave their country of origin because of persecution, but for economic reasons, cannot enjoy the protection regime enshrined in The 1951 Refugee Convention and its Additional Protocol 1967 (Trocan, 2014: 155).

An interesting problem arises in the case of the concept of "expat". The Romanian equivalent is the term "expatriate" (MDA II, 2010) which, according to MDA II (2010), designates a person who is obliged to leave his or her homeland or a person who leaves his or her homeland to settle (permanently or temporarily) in another country. The term "expat" is used in the modern society to refer to a person who lives, temporarily and for work purposes, in a country other than that of which he or she is a national. Usually, the migrant worker is a professional and occupies a position outside his / her country of origin, either independently or seconded (detached) by the employer.

The problem arises when differentiating between "expat" and "immigrant". Unlike immigrants, who move to another country with the intention of settling permanently, the expatriate distinguishes by the temporary character of the migration.

Yvonne McNulty, a university lecturer specializing in Human Resources management and expatriation at the University of Social Sciences in Singapore, developed a word definition in 2016 with her colleague, Chris Brewster, describing a number of conditions that a person must meet in order to be classified as an "expat": a) to temporarily live outside the country of origin; b) to fulfill the legal conditions to live and work in the country in which they are located; c) not be a citizen of that country. McNulty also considered that although the term is often used to describe high-status migrants - which she defines as highly paid and with higher education - the term "expat" is not used in the case of unskilled foreign workers as they are categorized as "economic migrants" (Sherhan, 2018).

However, whom do we consider "immigrant" and whom do we consider "expat"? An American diplomat in Rwanda, an Ukrainian electrician in London, a Moroccan student doing her studies in France, a Swedish businesswoman in Shanghai, or a Syrian teacher working as a janitor in Germany?

By definition, all of the aforementioned should be called "expats" because they live outside the country of origin for an indefinite period of time, but unfortunately the reality is different. As Mawuna Remarque 
Koutonin points out in The Guardian, the term "expat" is reserved exclusively for Western white people who go to work abroad (Koutonin, 2015). The Wall Street Journal, the world's largest financial information magazine, presented the following conclusion on a blog dedicated to the expatriate life: "Some arrivals are described as expats; others as immigrants; and some simply as migrants. It depends on social class, country of origin and economic status. It's strange to hear some people in Hong Kong described as expats, but not others. Anyone with roots in a western country is considered an expat ... Filipino domestic helpers are just guests, even if they've been here for decades. Mandarin-speaking mainland Chinese are rarely regarded as expats ... It's a double standard woven into official policy" (DeWolf, 2014).

Unlike refugees, who cannot return home safely, voluntary migrants do not encounter such obstacles. If they choose to return home, they will continue to receive the protection of their government.

Forced migrants are those individuals who are determined to leave their habitual residence because of events that threaten their life or safety. Forced migration has many causes and thus takes many forms. People are leaving because of persecution, violations of human rights, conflicts, repression and natural or man-made disasters. Many leave out of their own initiative to avoid potential life-threatening situations, although in more and more cases the population is driven away by governments or insurgent groups that aim to depopulate or seek to change their ethnic or religious composition from a certain area.

The definition of forced migrants includes both people crossing international borders in search of asylum and internally displaced persons (Turton, 2003: 6; Moldovan, 2008: 109). It has been shown that the United Nations is experiencing an increase in the number of internal relocations. Internally displaced persons are those who are forced to leave their normal place of residence, but to remain on the territory of the country of origin, thus being excluded from the refugee protection system.

The United Nations High Commissioner for Refugees (UNHCR), mandated to lead and coordinate global refugee protection, does not use the term provided by the Convention. UNHCR uses the term "persons of concern" which has a broader acceptance, including refugees, persons in similar situations, returnees, internally displaced persons, asylum seekers and stateless persons.

Refugees are in the category of forced migration, in which internally displaced persons are included. The main difference between the two categories of persons is given by the fact that the refugees are outside their home state, which they leave because of persecution, thus lacking the protection of the 
respective state, while the displaced persons are still within the borders of the state of origin under whose protection, in theory, they continue to be (Turton, 2003: 6; Moldovan, 2008: 109).

Also, another difference between refugees and displaced persons is given by the legal regime that applies to the two categories. The status of refugees has an important consequence, namely: the guarantee against expulsion, represented by the principle of non-refoulement. The displaced persons benefit from the protection of humanitarian law (Casanovas, 2003; Moldovan, 2008: 110).

Although they are a subcategory for forced migration, refugees are privileged with a special status established by international law through the regulations of the UN Convention and the Protocol on the Status of Refugees.

According to Article 1 of the 1951 Geneva Convention of the United Nations on the Status of Refugees and the Protocol on the Status of Refugees of 1967, "The term refugee applies to any person [...], who, [...] rightly fearing that he will be persecuted because of his race, religion, nationality, belonging to a social group or because of political opinions, is outside the borders of the country of which it has a nationality and which cannot or, because of these fears, does not wish to seek the protection of this state; or who, is not a national and is located outside the country where he had his habitual residence, as a result of such events, he cannot or, because of this fear, does not want to return there."

There are other definitions of the term - albeit at regional level - that better fit the practical reality, one of them being given by the Cartagena Declaration on Refugees (1984), an agreement adopted in Cartagena, Colombia by the International Protection Colloquium of refugees in Central America, Mexico and Panama. Thus, the Declaration defines the refugee as "a person who left his country of origin because his life, safety or freedom was threatened by widespread violence, foreign aggression, internal conflicts, serious violations of fundamental buman rights or other circumstances that disturbed the public order".

However, the most comprehensive definition is given by the OAU Convention Governing the Specific Aspects of Refugee Problems in Africa (La convention de l'OUA, Regissant les aspects propres aux problemes des refugies en Afrique), adopted on 10 September 1969, motivated by the fact that the 1951 Convention provisions did not correspond to African reality that was facing inflows of refugees caused by some unforeseen circumstances that were not covered in the Convention, such as national liberation wars and civil wars (Moldovan, 2015: 171).

According to article 1.2. of the African Convention "the term $<<$ refugee $>>$ shall also apply to every person who, owing to external aggression, 
occupation, foreign domination or events seriously disturbing public order in either part or the whole of his country of origin or nationality, is compelled to leave his place of habitual residence in order to seek refuge in another place outside his country of origin or nationality". However, the 1951 Convention on the Status of Refugees does not guarantee the right of asylum seekers to be sheltered by certain states. However, if the persons concerned are allowed to stay in the territory of the states, they are granted a privileged status.

Within the European Union, the term "refugee" refers to "any thirdcountry national who, owing to a well-founded fear of being persecuted for reasons of race, religion, nationality, political opinion or membership of a particular social group, is outside the country of nationality and is unable or, owing to such fear, is unwilling to avail bimself or herself of the protection of that country, or a stateless person, who, being outside of the country of former habitual residence for the same reasons as mentioned above, is unable or, owing to such fear, unwilling to return to it, and to whom Article 12 does not apply" (Directive 2011/95/EU of the European Parliament and of the Council of 13 December 2011 on standards for the qualification of third-country nationals or stateless persons as beneficiaries of international protection, for a uniform status for refugees or for persons eligible for subsidiary protection, and for the content of the protection granted).

According to this regulation, the definition of the term "refugee" involves three elements: physical, psychological and causal. Thus, from a physical point of view, the refugee is a person who has left the territory of his country and is in the territory of another state. This element differentiates the refugee from another category of migrants, that of internally displaced persons, who leave their habitual residence for similar reasons, but who did not cross the border of their state, remaining in its territory.

From a psychological point of view, the granting of the refugee status is determined by proving a fear of persecution for well-defined reasons in the aforementioned text (belonging to a race, to a religion, to a nationality, to a social group or to the expression of political opinions) constitutes the causal element (Moldovan, 2008: 101-102).

Initially, in the text of the 1951 Convention, there was a requirement, materialized within a time limit, namely the requirement that the situation of persons be the result of an event occurring prior to January $1^{\text {st }}, 1951$. The Protocol of January 31 ${ }^{\text {th }}$, signed in New York in 1967 (United Nations, 1967) eliminated this time limit, a consequence of the emergence of new inflows of refugees following the adoption of the 1951 Convention, which, by drawing this limit, would have been excluded from the conventional protection framework. 
The delimitation of the term "asylum seeker" from the term "refugee" is all the more necessary as the use of these terms creates confusion even if their status is different.

The asylum seeker is the person seeking safety against persecution in a country other than his or hers and is awaiting a decision on the application for refugee status under relevant international and national instruments. In the case of a negative decision, the person must leave the country and can be expelled as well as other aliens in a similar situation of clandestinity or illegal stay, unless the permission to stay on the territory of the host state is granted for humanitarian reasons.

Every refugee is initially an asylum seeker, but not every asylum seeker will eventually be recognized as a refugee. While waiting for their application to be accepted or rejected, these persons are called asylum seekers.

A definition given by UNESCO presents asylum seekers as those who travel abroad looking for the protection of another state, but who do not strictly meet the criteria established by the 1951 Convention. The term "asylum seeker" defines the person who has applied for refugee protection and awaits the establishment of its status. The term "refugee" is used to describe a person who has already been granted protection by a state. Thus, asylum seekers can become refugees if the authorities of the respective state consider that they fall within the international definition of the refugee, more precisely that they fulfill the conditions necessary for granting this status.

The definition of asylum differs from state to state, with national asylum systems being designed to decide which asylum seeker qualifies for international protection.

Asylum is a form of protection granted by a state on its territory, based on the principle of principle of non-refoulement and the rights recognized internationally or nationally, which are granted to a person who cannot seek protection in the country of citizenship and for fear of being persecuted for reasons of race, religion, nationality, belonging to a certain social group or political opinions.

The national and international legal doctrine (scientia iuris) discusses two forms of asylum: territorial and diplomatic. Of these, international law recognizes territorial asylum as the true form of protection, which is characterized as a humanitarian act of a state that grants protection on its territory to a person that has fled his country of origin due to persecution. In order to benefit from territorial asylum, it is necessary to submit an application at the external borders or in the territory of the host state. 
However, practice shows that, for centuries, in addition to the classical and main category of territorial asylum, cases of asylum in diplomatic spaces have been close in number (Morgenstern, 1948: 236-261; Hitaj, 2016: 2).

The concept of diplomatic asylum in international law has generated controversy between the laws of Europe and those of Latin America. On one hand, the right to diplomatic asylum is considered to be an act against the sovereignty of the receiving state and contravenes the diplomatic laws and, on the other hand, Latin America considers asylum an opportunity to defend the lives and freedom of people who are criminally prosecuted for their political views. However, this institution is regulated and enforced in Latin American countries, but rarely in other territories (Chatterjee, 2007; Malinowska, 2014)

Latin America is the only continent in which the two institutions are regulated and used in accordance with the law (Gros Espiell, 1982; Malinowska, 2014).

Asylum, including the legal framework established by the 1951 Convention and the 1967 Protocol, derives directly from the right to seek and obtain asylum, as stated in Article 14 of the Universal Declaration of Human Rights ("UDHR"). This right has been reaffirmed on numerous occasions and in other regional instruments on refugees and human rights, including in the Charter of the European Union (Charter Of Fundamental Rights Of The European Union, 2012), which, in Article 18, states that "The right to asylum shall be guaranteed with due respect for the rules of the Geneva Convention of 28 July 1951 and the Protocol of 31 January 1967 relating to the status of refugees and in accordance with the Treaty on European Union and the Treaty on the Functioning of the European Union (hereinafter referred to as "the Treaties")".

Most people who leave their home of residence to escape persecution and armed conflict either stay in their country as internally displaced persons, or seek asylum as refugees in neighboring or near states. In other words, they remain in the region of origin. Between 1992 and 2001, for example, developed countries hosted on average more than $70 \%$ of the refugee population globally.

While most refugees remain in their home regions, an increasing number are heading to industrialized states in Western Europe, North America and even Australia and Japan. Thus, they join a wider flow of international migrants whose primary purpose is to seek employment, achieve a better standard of living or to join other family members already established in that state.

In fact, it has become increasingly difficult to make a clear distinction between refugees and other international migrants. In many 
cases, the population moves from one state to another in response to a complex set of threats and difficulties. Fear of persecution and the threat of violence may coexist with the desire to have access to the opportunities, services and resources available in developed states (Crisp, 2003: 7).

For governments, differentiating between voluntary and forced migrants is important. States deal with migrants according to their own immigration laws and procedures. Adjacently, it deals with refugees through their protection norms and asylum procedures that are defined in national law and international law, having a multitude of responsibilities vis-à-vis asylum seekers in their territory.

\section{The causes and effects of migration}

The flows of international migration have increased in amplitude and complexity over the last decades. The phenomenon of migration was analyzed mainly through the concept of the push-pull factors. This concept differentiates between the factors that cause people to leave their country ("push factors"), representing the negative aspects of the country of origin and the factors that attract migrants to a particular country ("pull factors"), representing the positive aspects of the receiving country.

Push-pull factors materialize in different forms and are often decisive in people's choice to migrate.

Factors regarding safety and security are usually of the highest importance in people`s decision to migrate, sometimes representing a matter of life and death. Persecution and discrimination based on nationality, race, religion, political beliefs or belonging to a social group, often causes people to move to other safer areas. The danger can be created by the activities of criminal groups or by war. A significant example is The Northern Triangle of El Salvador, Guatemala and Honduras, considered the most dangerous place in the world. All three countries register thousands of crimes committed by local and international gangs, $95 \%$ of these crimes remaining unpunished, a consequence of corruption and under-funded institutions. The number of asylum seekers originating from the Northern Triangle reached 110,000 in 2015, an increase of five times from 2012 (Labrador \& Renwick, 2018).

Economic factors cause the population to migrate from poorer areas to developed areas where wages are higher and employment opportunities are more numerous and varied. Most often, the population emigrates due to unemployment, underdevelopment, unfavorable economic conditions and lack of career prospects. At the same time, in developing countries, technology and mechanization in the agricultural sector significantly reduce 
the need for labor in rural areas. Hence, the population has no alternative sources of income. Such a context was present in Romania, which, due to its fresh accession to the European Union, represented an important "source" of migrants for the western countries. Such a country is Italy, where Romanians are the main minority $(1.8 \%$ of Italy's total population is represented by Romanian migrant citizens) (Sawe, 2018).

Environmental factors cause the migration of the population because of both natural hazards and their aftermath. Drought results in food shortages and hunger; pollution of water, air and soil creates major risks to the health of the inhabitants, forcing them to migrate to low risk areas. At the same time, natural disasters such as tsunamis, hurricanes and earthquakes, are often compelling reasons to migrate.

The social factors that cause migration stem from people's need and desire to achieve a higher standard of life. Thus, they migrate to ensure a better life for themselves and their family, in regards to the community (for example, the increased level of tolerance for cultural, sexual, ethnic and religious diversity), the education system and the health system.

In order to fully understand the role that migration plays in socioeconomic development, it is necessary to analyze the effects and the impact that this phenomenon has on both the countries of origin and the host countries.

Firstly, the economic effects are visibly positive. As a result of the increase in the number of migrants, the GDP per capita increases significantly, while the level of unemployment decreases. This improvement of the economic situation also has a positive effect on public finances: as public expenditures increase, so do revenues from taxes and contributions. Regarding the flow of asylum seekers, no significant effect was noted as this is a special form of immigration. Most European countries host asylum seekers during their asylum applications, but they are not authorized to work during this period. As a result, the anticipated economic contribution of asylum seekers is lower than that of permanent migrants for whom there are no employment restrictions (d'Albis, Boubtane, \& Coulibaly, 2018).

The economic effects of migration vary widely. The sending countries can have both short-term gains and losses, but they can also benefit from long-term gains. For beneficiary countries, the integration of migrant workers helps to resolve skills shortages, but can reduce internal wages, thus creating a burden for the well-being of the population.

For the sending countries, the short-term economic benefit of emigration can be found in remittances. Remittances are funds that migrants 
earn abroad and send back to their countries of origin, mainly to support the families left behind.

An interesting effect of migration appears in developing countries and it stems from the fact that a large number of highly skilled and educated citizens choose to migrate - the so-called "brain-drain" phenomenon. It refers to the international transfer of human capital resources and mainly applies to the migration of highly qualified people from developing countries to developed countries. In practice, the term is used in a narrower sense and it defines the case of migrants with university education or professionals in fields such as engineering, medicine and science (Docquier, 2014).

There are several negative effects both on the country from which the skilled population emigrates and on the economies of the countries to which they are heading. This phenomenon implies the depletion of the human capital stock of the poor countries, which consequently damages their prospects for economic development. Talented people are born, raised and educated in their country and when the time to work and give back what they have been offered comes, they choose to emigrate and look for a job in another country.

At the same time, while developing countries lose their skilled workforce, developed countries end up having an overabundance of skilled workers trying to enter the workforce and thus fewer jobs are available (Srivastava, 2018).

The positive part of this phenomenon is the fact that the population in poor countries considers that the level of education is a safe way to migrate to the developed countries. As a result, the prospect of future emigration stimulates them to give more effort and importance to education and professional development.

From the point of view of social effects, migration can have both positive and negative consequences, as follows: a richer and more diverse culture; developing tolerance and promoting multiculturalism; access of migrants to a better education and health system; tensions caused by cultural, racial and religious differences; language barriers; over-crowding of urban areas; and increasing crime.

Therefore, migration is a phenomenon of great importance in terms of cultural enrichment of societies, broadening the spectrum of opportunities and supporting socio-economic changes. At the same time, one of the great challenges is the manifestation of extremist ideologies that incite to violations of the legal framework, with the involvement of some of the migrants or even of the indigenous population, thus causing a climate of public insecurity. 


\section{Conclusion}

The large-scale movement of people is a defining feature of globalization and has always played a major role in colonialism, industrialization, the emergence of nation-states and the development of the capitalist world market. States are often reluctant to open the borders to foreigners because there is the fear that their own culture, the specifics of the population, but also their jobs are likely to be affected by uncontrolled immigration. At the same time, companies need migration to support economic growth. Migration is not a mere act of crossing the border, but an important factor in the erosion of traditional boundaries between languages, cultures, ethnic groups and nation-states, affecting all those involved.

Many states are ideologically committed to opening their borders because their national identities are historically and traditionally based on migration. Other states that have not historically experienced migration tend to be less open and tolerant, a situation in which a social conflict can develop between natives ansd newcomers, which can be seen as "polluting" factors of national culture and identity.

Moreover, due to the fact that migration represents a very important and current issue of our society, it is mandatory to have a clear distinction and representation of the terms used, such as "refugee", "asylum seeker", "immigrant", "expat" in order to better understand the controverses in this field.

Migration is influenced by a combination of factors: economic, political and social - either in the country of origin of the migrants ("push factors") or in the country of destination (attraction factors or "pull factors").

Historically, the economic prosperity and political stability of the developed regions has been the context that has been an attraction factor for migrants. In these countries, international migration can be used as a tool to address a specific shortage of the labor market. At the same time, international migration also benefits in the context of the aging population of the developed states.

It should be noted that most of the states that receive migrants tend to face negative reactions to large migrant flows, creating an overwhelming situation for the receiving state. On the other hand, nations that send migrants often benefit from the remittances that result from higher wages in the countries of destination, but tend to experience the "brain drain" of skilled and educated professionals, thus generating a negative impact on their population, as well as on the economic development of the state. Labor migration is, however, desirable and even necessary to support the economic 
growth and important for the transfer of the skills needed for the development of society at global level.

Migration as a whole captures a dynamic, constantly changing reality where the reasons and causes for which people migrate are varied and complex. People migrate because of persecution, violations of fundamental human rights, poverty, wars, natural disasters or simply seeking a better life. The distinction between the causes of migration is not very clear, and the limits set by international law do not always reflect the reality of migrants' lives.

However, migration will continue to be a major and unstoppable factor of society at a global level, until the various determining and attraction factors, including economic disparities between sending and receiving states, are eliminated. Human mobility cannot be something to fight against, but rather something to be embraced.

\section{References}

Academia Română. (2010). Micul dicţional academic (MDA) [The Little Academic Dictionary] (2 $2^{\text {nd }}$ ed.). Bucharest, Romania: Univers Enciclopedic.

Academia Română, Institutul de Lingvistică „Iorgu Iordan”. (1998). Diç̦ionarul explicativ al limbii romane (DEX) [The explanatory dictionary of the Romanian language] (2nd ed.). Bucharest, Romania: Univers Enciclopedic.

Altermatt, U. (2000). Previriunile din Sarajevo [Predictions from Sarajevo]. Iaşi, Romania: Polirom.

Balan, M. (2015). Drept constituțional și instituții politice [Constitutional law and political institutions] (1 ${ }^{\text {st }}$ vol.). Bucharest, Romania: Hamangiu.

Casanovas, O. (2003). La protection internationale des réfugiés et des personnes déplacés dans les conflits armés, Recueil dec cours de l'Académie de droit international de la Haye [International protection of refugees and displaced persons in armed conflict, Proceedings of the Hague Academy of International Law course] (306 th vol.). Leiden, Germany: M. Nijhof.

European Union. (2012). Charter of Fundamental Rights of the European Union.

Retrived from https://eur-lex.europa.eu/legalcontent/EN/TXT/HTML/?uri=CELEX:12012P/TXT\&from=EN

Chatterjee, C. (2007). International law and diplomacy. London, UK: Routledge.

Colloquium on International Protection for Refugees and Displaced Persons in Central America (1984). Cartagena Declaration on Refugees. Cartagena, Columbia. Retrieved from https://www.oas.org/dil/1984_cartagena_declaration_on refugees.pdf 
Crisp, J. (2003). New Issues in Refugee Research, Working Paper No. 100. A new asylum paradigm? Globalization, migration and the uncertain future of the international refugee regim. Geneva, Switzerland. Retrieved from https://www.unhcr.org/3fe16d835.pdf

D’Albis, H., Boubtane, E., \& Coulibaly, D. (2018). Macroeconomic evidence suggests that asylum seekers are not a "burden" for western european countries. Science Advances, 4(6). doi:10.1126/sciadv.aaq0883

DeWolf, C. (2014). In Hong Kong, just who is an expat, anyway? The Wall Street Journal. Retrieved from https://blogs.wsj.com/expat/2014/12/29/inhong-kong-just-who-is-an-expat-anyway/.

Docquier, F. (2014). The brain drain from developing countries. IZA World of Labor. doi:10.15185/izawol.31

Dragoman, I., \& Ungureanu, D. (2018). Tratat de drept internațional umanitar [Treatise on international humanitarian law]. Bucharest, Romania: Universul Juridic.

Dupuy, P. M. (1996). Droit international public [nternational public law]. Paris, France: Dalloz-Sirey.

European Parliament and of the Council. (2011). Directive 2011/95/EU on standards for the qualification of third-country nationals or stateless persons as beneficiaries of international protection, for a uniform status for refugees or for persons eligible for subsidiary protection, and for the content of the protection granted, 2011. Retrieved from https://eurlex.europa.eu/legal-content/EN/TXT/?uri=celex\%3A32011L0095

Gros Espiell, H. (1982). El derecho internacional americano sobre asilo territorial y extradicion en sus relaciones con la Convencion de 1951 y el Protocolo de 1967 sobre estatuto de los refugiados [American international law on territorial asylum and extradition in its relations with the 1951 Convention and the 1967 Protocol on refugee status]. In J. Carpizo (Ed.), Asilo y proteccion internacional de refugiados en America Latina relatione (pp. 33-82). Mexico City, Mexico: Universidad Nacional Autonoma de Mexico.

Hitaj E. (2016). Diplomatic asylum under international law: between administration of justice, diplomatic immunity and human rights protection. International Journal of Law and Legal Jurisprudence Studies, 4(2), 36-56.

International Organization for Migration (IOM). (2011). Glosar asupra migrației. Drept Internațional al Migrației [Glossary on migration. International migration law], 25. Retrieved from https://www.oim.ro/index.php/ro/presa/aparitii-presa/365-cnn

Koslowski, R. (2011). Global mobility regimes. New York, USA: Palgrave Macmillan.

Koutonin, M. R. (2015). Why are white people expats when the rest of us are immigrants? The Guardian. Retrieved from 
https://www.theguardian.com/global-development-professionalsnetwork $/ 2015 / \mathrm{mar} / 13 /$ white-people-expats-immigrants-migration

La convention de l'OUA. (1969). Regissant les aspects propres aux problemes des refugies en Afrique [The Convention governing the specific aspects of refugee problems in Africa]. Retrieved from https://www.unhcr.org/about-us/background/45dc1a682/oauconvention-governing-specific-aspects-refugee-problems-africaadopted.html.

Labrador, R. C., \& Renwick, D. (2018). Central America's violent northern triangle in Council on Foreign Relations website. Retrieved from http://www.cfr.org/transnational-crime/central-americas-violentnorthern-triangle/p37286

Longman Dictionary of Contemporary English. (2005). London, UK: Pearson Longman.

Malinowska, A. (2014). The institution of diplomatic asylum as the possibility of protecting human rights. Lublin, Polland: Marie Curie-Sklodowska University in Lublin. Retrieved from http://www.culturaldiplomacy.org/academy/content/pdf/participantpapers/2014-04-lhrs/Alina Malinowska The institution of diplomatic asylum as the possibility of protecting human rights.pdf.

Moldovan, C. (2015). Drept international public [International Public Law]. Bucharest, Romania: Hamangiu.

Moldovan, C. (2008). Refugiații - subiecți ai migrării forțate [Refugees - subjects of forced migration]. Analele Stiințtifice ale Universității "Al. I. Cuza" Iași, Tomul LIV, Stiinte Juridice, 1, 101-112. Retrieved from https://laws.uaic.ro/files/docs/articole/2008/Anale2008 Complet Facult ateaDeDrept.pdf

Money, J., \& Taylor, T. W. (2016). Voluntary international migration. In P. James (Ed.), Oxford Bibliographies - International Relations. New York, USA: Oxford University Press. doi:10.1093/obo/9780199743292-0167

Morgenstern, F. (1948). Extra-territorial' asylum. British Year Book of International Law, 25, 236-261.

Pătulea, V. (2010). Tratat de management juridic și jurisdicțional [Treatise on legal and judicial management]. Bucharest, Romania: IRDO.

Plutarch. (1949). Moralia, De Exilio. Retrived from https://www.gutenberg.org/files/23639/23639-h/23639h.htm\#Page 378a

Rosenberg, M. (2019). Push-pull factors in immigration. Retrieved from www.thoughtco.com/push-pull-factors-1434837 
Sawe, B. E. (2018). Largest ethnic groups of Italy. Retrieved from https://www.worldatlas.com/articles/largest-ethnic-groups-ofitaly.html\#goToCom.

Sherhan, Y. (2018). 'Expat' and the fraught language of migration. Washington, DC, USA: The Atlantic.

Srivastava, B. (2018). Economic impact of brain drain in developed and developing countries. New Jersey, USA: William Paterson University.

Sulima, S. (2015). Migration and mobility within the framework of the European neighbourhood policy. In Social sciences and management (pp. 282-291). Târgu Mureş, Romania: Arhipelag XXI. Retrieved from https://www.researchgate.net/publication/321267673 Migration and Mo bility within the Framework of the European Neighbourhood Policy in East

Trocan, L. M. (2014). Drept internațional public [International Public Law]. Bucharest, Romania: C. H. Beck.

Turton, D. (2003). Refugees and 'Other forced migrants'. Retrieved from: https://www.rsc.ox.ac.uk/files/files-1/wp13-refugees-other-forcedmigrants-2003.pdf

United Nations Department of Economic and Social Affairs. (2017). Population division. International migration. Retrieved from https://migrationdataportal.org/data?i=stock abs \&t=2017

United Nations High Commissioner for Refugees. (2018). Annual Global Trends report. Retrieved from https://www.unhcr.org/news/stories/2018/6/ 5b222c494/forced-displacement-record-685-million.html

United Nations Educational, Scientific and Cultural Organization. (n.d.). Migration and inclusive societies. Retrieved from http://www.unesco.org/new/en/social-and-humansciences/themes/international-migration/glossary/

United Nations. (1967). The Convention Relating to the Status of Refugees, Geneva, 1951 and its Additional Protocol. Retrieved from https://www.unhcr.org/1951-refugee-convention.html

United Nations. (1976). The International Covenant on Civil and Political Rights. New York, USA. Retrieved from https://www.ohchr.org/en/professionalinterest/pages/ccpr.aspx

United Nations. (1948). Universal Declaration of Human Rights. Paris, France. Retrieved from https://www.un.org/en/universal-declaration-humanrights /

Williams, A. M. (2006). Lost in translation? International migration, learning and knowledge. Progress in Human Geography, 30(5), 588-607. doi:10.1177/0309132506070169 